\title{
STRATEGI KOMUNIKASI DINAS PARIWISATA KOTA PALEMBANG DALAM MEMPROMOSIKAN DESTINASI WISATA DI KOTA PALEMBANG MENJELANG ASIAN GAMES XVIII 2018 (Studi pada Program Paket Wisata Hemat "Palembang Asiik")
}

\author{
Aprilyanti Pratiwi \\ Mahasiswi Program Doktor \\ Program Studi Komunikasi Pembangunan Pertanian Pedesaan \\ Fakultas Ekologi Manusia \\ Institut Pertanian Bogor \\ aprilyanti.mikom@gmail.com
}

\begin{abstract}
ABSTRAK:
Potensi pariwisata yang dimiliki kota Palembang belum secara optimal digali. Hal ini menyebabkan hanya sedikit objek wisata saja yang dikenal oleh masyarakat luar Palembang, baik domestik maupun mancanegara. Umumnya, objek wisata khas kota Palembang yang dikenal oleh masyarakat luar Palembang hanyalah Jembatan Ampera saja. Padahal masih banyak objek wisata lainnya di kota Palembang yang dapat menjadi destinasi wisata bagi wisatawan. Terkait hal tersebut, permasalahan yang dihadapi oleh Pemkot sejauh ini adalah kurang optimalnya promosi yang dilakukan. Untuk itu diperlukan strategi komunikasi untuk mempromosikan destinasi wisata yang ada di kota Palembang agar dapat meningkatkan kunjungan wisman ke kota Palembang. Terlebih Palembang akan menjadi tuan rumah pada perhelatan Asian Games XVIII 2018. Kota Palembang dapat memanfaatkan momen tersebut dalam melakukan percepatan pertumbuhan sektor pariwisatanya. Berdasarkan permasalahan tersebut, maka tujuan penelitian ini adalah untuk mengetahui bagaimana strategi komunikasi yang dilakukan oleh Dinas Pariwisata Kota Palembang dalam mempromosikan destinasi wisata di kota Palembang menjelang Asian Games XVIII 2018 melalui program paket wisata hemat "Palembang Asik". Penelitian ini menggunakan formula komunikasi Lasswell untuk menganalisis menganai siapa komunikator, apa pesannya, apa saja media yang digunakan, siapa khalayak sasarannya, serta apa efek yang ditimbulkan. Metode yang digunakan pada penelitian ini adalah deskriptif kualitatif dengan pengambilan data: observasi dan dokumentasi. Hasil menunjukkan bahwa Dinas Pariwisata Kota Palembang memilih 20 biro perjalanan wisata yang tergabung dalam Asosiasi Perusahaan Perjalanan Wisata Indonesia (Asita) Provinsi Sumatera Selatan sebagai komunikator. Pesan yang diusung melalui paket wisata "Palembang Asiik" yaitu aman, seru, irit, indah, dan kenangan. Media yang digunakan untuk mempromosikan program ini diantaranya adalah media baru dan pelaksanaan event-event pariwisata. Khalayak sasaran dalam program wisata ini adalah wisatawan mancanegara, khususnya Asia. efek yang didapatkan dari strategi komunikasi yang dilakukan oleh Dinas Pariwisata Kota Palembang dalam mempromosikan program Paket Wisata Hemat "Palembang Asiik" ini adalah meningkatnya jumlah wisatawan, khususnya wisatawan asing yang datang ke kota Palembang.
\end{abstract}




\section{National Conference of Creative Industry: \\ Sustainable Tourism Industry for Economic Development}

Universitas Bunda Mulia, Jakarta, 5-6 September 2018

E- ISSN No: 2622-7436

Kata Kunci: strategi komunikasi, dinas pariwisata kota Palembang, promosi wisata, Asian Games VXIII 2018

\section{ABSTRACT:}

The potential of tourism owned by Palembang city has not been optimally excavated. It causes only a few tourist objects are known by people outside of Palembang, both domestic and foreign.Generally, the typical tourist attraction of Palembang city that is known by people outside Palembang is Ampera Bridge only. Though there are many other attractions in Palembang which can be a tourist destinations. Related on it, the problems faced by the City Government is less than optimal campaigns made. A communication strategy is needed to promote the existing tourist attractions in Palembang in order to increase the visits of foreign tourists to Palembang. Especially Palembang will host the 2018 Asian Games XVIII event. Palembang city can use these moments in accelerating the growth of its tourism sector.Based on these problems, the purpose of this study is to find out how the communication strategy undertaken by the Department of Tourism of Palembang City in promoting tourist destinations in Palembang before Asian Games XVIII 2018 through a package tour program "Palembang Asiik". This research will use Lasswell's communication formula to analyze who is the communicators, what messages, what media are used, who the target audience is, and what effects they have. The method used in this research is descriptive qualitative with data taking: observation and documentation. The result shows that communicator in this research, is Association of Indonesian Travel Company (Asita) South Sumatera Province. Messages that are carried through the package tour is safe, exciting, efficient, beautiful, and memories. Media used to promote this program include new media, through Instagram. Target audiences in this tour program are foreign tourists, especially Asia. The effect of this program is increasing the number of tourist.

Keywords: communication strategies, government tourism office of Palembang, promotion tour, Asian Games XVIII 2018,

\section{PENDAHULUAN}

Palembang, salah satu ibu kota provinsi di pulau Sumatera. Sebagai kota terbesar kedua di pulau Sumatera setelah Medan $^{1}$, Palembang terus-menerus melakukan pembagunan. Salah satu aspek pembangunan yang terjadi di Palembang yaitu pada infrastruktur terkait penyelenggaraan Asian Games XVIII di Kota Palembang. Sejatinya ajang Asian Games XVIII dapat dijadikan kesempatan bagi dinas pemerintahan kota Palembang dan dinas terkait untuk meningkatkan pendapatan daerah dengan menjual objek pariwisata yang ada di Kota Palembang. Namun sayangnya, selama ini potensi pariwisata di Kota Palembang belum digali secara optimal. Imbasnya, sangat sedikit masyarakat luar kota Palembang yang mengenal objek wisata yang ada di Kota Palembang. Masyarakat luar kota Palembang selama ini hanya mengetahui Jembatan

\footnotetext{
${ }^{1}$ Berdasarkan sumber Kemendagri tahun 2015, Medan berada di posisi ketiga sebagai kota terpadat penduduknya setelah Jakarta dan Surabaya dengan jumlah populasi 2.465.469 jiwa. Sedangkan Palembang berada di posisi ketujuh dengan jumlah populasi 1.548.064 jiwa.
} 


\section{National Conference of Creative Industry: \\ Sustainable Tourism Industry for Economic Development}

Universitas Bunda Mulia, Jakarta, 5-6 September 2018

E- ISSN No: 2622-7436

Ampera yang merupakan ikon wisata kota Palembang. Padahal Palembang memiliki banyak objek wisata lainnya yang sangat menarik untuk dikunjungi, seperti Benteng Kuto Besak, Hutan Wisata Punti Kayu, Taman Purbakala Kerajaan Sriwijaya, Kampung kapitan, kampung Arab, dan lain-lain.

Pemerintahan Kota Palembang selama ini mengakui belum melakukan promosi pariwisata dengan optimal. Momen Asian Games diyakini tepat untuk mempromosikan pariwisata ko Palembang kepada masyarakat luar Palembang, baik domestik maupun mancanegara. Pemkot Palembang dan Dinas Parisiwata kota Palembang pun melakukan strategi untuk mempromosikan pariwisata di Kota Palembang.

Cangara (2014) menyatakan bahwa perlu kehati-hatian dalam memilih strategi komunikasi. Jika kita memilih strategi yang salah maka akan menghasilkan kesalahan dan kerugian, utamanya kerugian dalam hal waktu, biaya, dan sumberdaya. Oleh karena itulah perlu dirancang strategi yang baik serta hati-hati agar tujuan strategi yang sudah kita rancang dapat tercapai. Akan tetapi, kehati-hatian pemilihan strategi pun belumlah cukup. Sangat penting untuk membuat audiens memahami pesan yang mereka terima. Pace et.al, sebagaimana dikutip dari Effendy (2007) menjelaskan bahwa dalam kegiatan komunikasi harus memiliki tiga tujuan, yaitu pertama harus memastikan para audiens memahami pesan yang mereka terima atau disebut dengan to secure undesrtanding. Kedua adanya pembinaan terhadap audiens atau to establish acceptance. Kemudian yang ketiga yaitu kegiatan komunikasi tersebut dimotivasikan atau to motivate action. Ketiga tujuan komunikasi ini hendaknya dilakukan agar tujuan dari dilaksanakannya strategi komunikasi dapat terwujud.

Dinas Pariwisata Kota Palembang merancang program paket wisata hemat "Palembang Asik" untuk mempromosikan desatinasi wisata di kota Palembang menjelang Asian Games XVIII 2018. Tentunya agar program ini dapat berjalan sesuai dengan tujuan, maka Dinas Pariwisata Kota Palembang harus merancang strategi komunikasi yang terencana dengan baik. Maka penting untuk diketahui lebih lanjut bagaimana strategi komunikasi yang dilakukan oleh Dinas Pariwisata Kota Palembang dalam mempromosikan program paket wisata "Palembang Asik".

\section{TINJAUAN PUSTAKA}

\section{Komunikasi}

Banyak ahli yang memberikan definisi terhadap komunikasi. Diantaranya yang terkenal adalah definisi yang dikemukakan oleh Everet M. Rogers, yaitu komunikasi merupakan proses pengalihan pikiran dari sumber kepada penerima yang dimaksudkan untuk mengubah perilaku penerima tersebut (Mulyana, 2012). Selanjutnya Carl I. Hovland juga memberikan definisi mengenai komunikasi, yaitu komunikasi merupakan suatu proses untuk mengubah perilaku orang lain (Effendy, 2007). Kemudian definisi komuniakasi lainnya dikemukakan oleh Harold Lasswell yaitu komunikasi adalah proses penyampaian pesan yang dilakukan oleh komunikator kepada komunikan dengan menggunakan media yang menghasilkan efek tertentu (Effendy, 2007).

Sebagaimana definisi komunikasi yang telah diberikan oleh para ahli tersebut maka dapat disimpulkan bahwa komunikasi merupakan proses penyampaian pesan, dapat berupa pikiran atau ide, yang dilakukan oleh seseorang atau komunikator kepada orang lain atau komunikan melalui media agar menghasilkan efek. Efek di sini dimaksudkan pada tujuan yang ingin dicapai dalam proses komunikasi, yaitu adanya perubahan perilaku yang terjadi pada diri komunikan. 


\section{National Conference of Creative Industry: \\ Sustainable Tourism Industry for Economic Development}

Universitas Bunda Mulia, Jakarta, 5-6 September 2018

E- ISSN No: 2622-7436

\section{Strategi}

Pada dasarnya, strategi merupakan suatu perencanaan (planning) dan manajemen (management) demi tercapainya suatu tujuan (Effendy, 2007). Sejarah mengenai strategi memiliki kunikan trsendiri. Sebagaimana dikutip dari Cangara (2014) dijelaskan bahwa awal mula lahirnya strategi adalah pada ranah militer. Dijelaskan bahwa strategi merupakan suatu konsep militer yang dapat dimaknai sebagai seni perang bagi para jenderal. Clausewitz mendefinisikan strategi sebagai sebuah seni yang menggunakan media pertempuran demi meraih tujuan perang. Selanjutnya MartinAnderson memaknai strategi sebagai seni yang di dalamnya terkandung kemampuan intelegensi untuk melibatkan sumberdaya yang ada demi mencapai tujuan dengan meraih keuntungan yang besar dan efisien.

Berdasarkan definisi para ahli tersebut dapat disimpulkan bahwa strategi merupakan suatu perencanaan yang dilakukan dengan melibatkan kemampuan berfikir serta memanfaatkan sumberdaya yang dimiliki demi meraih tujuan tertentu.

\section{Strategi Komunikasi}

Middlelton menjelaskan bahwa strategi komunikasi adalah semua elemen komunikasi seperti komunikator, pesan, media, komunikan dan efek yang dikombinasikan dan dirancang demi optimalnya tujuan komunikasi yang diraih (Cangara, 2014).

Effendy (2007) mendefinisikan strategi sebagai suatu perencanaan komunikasi (communication planning) dan manajemen (communication management) demi tercapainya tujuan komunikasi yang telah dibuat.

Berdasarkan definisi strategi komunikasi di atas, dapat disimpulkan bahwa strategi komunikasi merupakan perencanaan yang dilakukan terhadap semua elemen komunikasi (komunikator, pesan, media, komunikan dan efek) untuk mendapatkan tujuan yang telah ditetapkan.

\section{Penetapan Strategi dalam Perencanaan Komunikasi}

Diperlukan beberapa elemen komunikasi pada suatu perencanaan strategi komunikasi. Pada penelitian ini digunakan elemen komunikasi menurut Lasswell yang menyangkut beberapa aspek, yaitu komunikator, pesan, media, audiens, dan efek (Cangara, 2014).

\section{Komunikator}

Komunikator merupakan seseorang dan atau sekelompok orang yang mengirimkan pesan kepada orang lain yang bertujuan untuk memengaruhi sikap, opini serta tindakan orang lain tersebut (Soemirat, 2014). Komunikator merupakan aktor utama dalam aktivitas komunikasi, maka dari itu komunikator memiliki peranan yang sangat penting. Oleh sebab itulah seorang komunikator dalam suatu program komunikasi harus memiliki kecakapan berkomunikasi, memiliki banyak ide, dan memiliki kreativitas yang tinggi.

2. Pesan

Simons sebagaimana dikutip dari Soemirat (2014) menjelaskan bahwa pesan merupakan apa-apa yang diucapkan oleh komunikator baik secara verbal (kata-kata dan tulisan) maupun non verbal (gerakan tubuh, nada suara, lirikan mata, dan lain-lain). 


\section{National Conference of Creative Industry: \\ Sustainable Tourism Industry for Economic Development}

Universitas Bunda Mulia, Jakarta, 5-6 September 2018

E- ISSN No: 2622-7436

Cangara (2014) menjelaskan bahwa pesan merupakan semua yang disampaikan oleh komunikator dalam bentuk simbol serta dipersepsikan dan diterima oleh komunikan dalam serangkaian makna. Berdasarkan bentuknya, simbol dapat dibedakan menjadi dua jenis, yaitu simbol verbal dan simbol non verbal. Simbol verbal pada penerapannya menggunakan bahasa, baik lisan maupun tulisan. Sedangkan simbol nonverbal pada penerapannya menggunakan bahasa tubuh (body language) atau bahasa diam (silent language). Kaitannya dengan program komunikasi, isi pesan harus disesuaikan dengan kepada siapa pesan tersebut akan didistribusikan. Pesan untuk masyarakat luas tentunya berbeda dengan pesan untuk masyarakat dengan komunitas tertentu.

\section{Media}

Media atau saluran merupakan wadah atau sarana yang digunakan untuk mendistribusikan pesan dari komunikator kepada komunikan (Soemirat, 2014). Media atau saluran komunikasi dapat dilakukan melalui tatap muka, interaksi kelompok maupun menggunakan media massa. Komunikator harus melakukan beberapa pertimbangan untuk memilih media komunikasi yang sesuai agar pesan yang disampaikan tepat sasaran sesuai tujuan. Diantaranya harus mempertimbangkan siapa khalayak yang akan dituju dan jenis media apa yang mereka gunakan. Untuk masyarakat luas hendaknya menggunakan media komunikasi massa seperti televisi, radio atau surat kabar. Sedangkan untuk masyarakat komunitas tertentu dapat menggunakan saluran komunikasi kelompok atau media luar ruangan seperti selebaran, brosur, poster atau pamflet. Saat ini juga dapat digunakan media baru untuk mendistribusikan pesan yang akan disampaikan kepada khalayak (Cangara, 2014).

\section{Audiens/Khalayak/Komunikan}

Audiens atau komunikan merupakan penerima pesan dari sumber atau komunikator (Mulyana, 2012) yang juga mrupakan target sasaran dari program komunikasi. Cangara (2014) menyatakan bahwa sangat penting untuk memahami karakteristik masyarakat yang akan menjadi target sasaran komunikasi. Hal ini disebabkan karena merekalah yang menjadi penentu bagi keberhasilan program komunikasi yang dirancang. Pada proses penerimaan pesan dan selanjutnya memaknai pesan tersbut, audiens atau komunikan dipengaruhi oleh berbagai macam aspek, diantaranya adalah pengalaman masa lalu, nilai-nilai, pengetahuan, persepsi, pola pikir, dan perasaan (Mulyana, 2012).

\section{Efek}

Efek merupakan hasil akhir dari penerimaan pada komunikan setelah ia menerima pesan dari komunikator (Mulyana, 2012). Efek komunikasi bermacammacam tingkatannya, mulai dari tidak tahu menjadi tahu (bertambahnya pengetahuan), tidak setuju menjadi setuju (perubahan sikap), dari yakin menjadi tidak yakin atau sebaliknya (perubahan keyakinan), dari tidak bersedia menjadi bersedia (perubahan perilaku).

Pada peristiwa komunikasi, kelima elemen komunikasi yang telah dijelaskan di atas saling berkaitan. Maka dari itu agar suatu program komunikasi dapat berjalan dengan baik dan efektif maka harus memanfaatkan kelima elemen tersebut dengan sebaik-baiknya. 


\section{National Conference of Creative Industry: \\ Sustainable Tourism Industry for Economic Development}

Universitas Bunda Mulia, Jakarta, 5-6 September 2018

E- ISSN No: 2622-7436

\section{Pariwisata}

Istilah pariwisata berasal dari bahasa Sangskerta yang terdiri dari dua suku kata, yaitu "pari" dan "wisata". "Pari" artinya banyak, berkali-kali, berputar-putar. Sedangkan "wisata" artinya perjalanan atau bepergian. Maka, jika disandingkan bersama, istilah pariwisata memiliki arti berputar-putar dari satu lokasi ke lokasi lainnya (Suryadana dan Oktavia, 2015).

Berdasarkan Undang-undang Kepariwisataan tahun 2009, pariwisata merupakan berbagai kegiatan wisata serta didukung beragam fasilitas dan layanan yang dilaksanakan oleh masyarakat, pengusaha, pemerintah, dan Pemerintah Daerah. Soekadijo (2000) mendefisikan pariwisata sebagai suatu kegiatan yang berkaitan dngan wisatawan.

Berdasarkan definisi di atas dapat disimpulkan bahwa pariwisata merupakan suatu kegiatan perjalanan yang dilakukan oleh wisatawan dari suatu tempat ke tempat lainnya.

\section{Kajian Penelitian Terdahulu}

Telah banyak penelitian terdahulu yang membahas mengenai strategi komunikasi pariwisata. Diantaranya adalah penelitian dengan judul Strategi Komunikasi Dinas Pariwisata, Pemuda dan Olahraga Kabupaten Kampar dalam Mempromosikan Wisata Candi Muara Takus yang ditulis oleh Erizon (2014). Hasil penelitian menunjukkan bahwa strategi Komunikasi Dinas Pariwisata Pemuda dan Olahraga Kabupaten Kampar dalam mempromosikan Wisata Candi Muara Takus yaitu dengan melaksanakan strategi pesan promosi yaitu berupa infrakstuktur, fasilitas dan paket wisata. Selain itu media massa yang digunakan adalah media cetak, elekronik dan internet. Selain itu digunakan media non massa atau event. Dinas Pariwisata Pemuda dan Olahraga Kabupaten Kampar juga memanfaatkan majalah dan buku dalam mempromosikan Wisata Candi Muara Takus.

Selanjutnya penelitian yang ditulis oleh Sugiarti et.al (2016) dengan judul Strategi Komunikasi Dinas Kebudayaan dan Pariwisata dalam Pemetaan Potensi Wisata Kabupaten Buton Tengah. Tujuan penelitian tersebut adalah untuk mengetahui strategi komunikasi yang dilakukan oleh Dinas Kebudayaan dan Pariwisata Kabupaten dalam melakukan pemetaan potensi wisata Kabupaten Buton Tengah. Selain itu tujuan penelitian tersebut adalah untuk mengetahui faktor-faktor yang memengaruhi strategi komunikasi yang dilakukan. Penelitian tersebut menggunakan konsep strategi perencanaan komunikasi menurut Anwar Arifin. Jenis penelitian tersebut adalah kualitatif dan dilakukan di Dinas Kebudayaan dan Pariwisata Kabupaten Buton Tengah. Dari hasil penelitian tersebut diketahui bahwa strategi yang dilakukan oleh Dinas Kebudayaan dan Pariwisata Kabupaten Buton Tengah yaitu mengenal khalayak, merancang pesan, menetapkan metode, dan menggunakan media. Tingginya potensi wisata kabupaten Buton Tengah, pemanfaatan teknologi komunikasi san perkembangan potensi wisata Kabupaten Buton Tengah merupakan faktor yang mendukung terlaksananya strategi komunikasi. Adapun faktor yang menjadi penghambat terlaksananya strategi komunikasi adalah belum meratanya perkembangan potensi wisata, belum baiknya akses menuju objek wisata, belum tersedianya dana dan infrastruktur serta belum baiknya penanggulangan sampah di daerah objek wisata.

Selain itu terdapat penelitian serupa lainnya yang dilakukan oleh Meilisa (2018) yang berjudul Strategi Komunikasi Dinas Pariwisata, Kepemudaan dan Olahraga, dan 


\section{National Conference of Creative Industry: \\ Sustainable Tourism Industry for Economic Development}

Universitas Bunda Mulia, Jakarta, 5-6 September 2018

E- ISSN No: 2622-7436

Kebudayaan Kabupaten Indragiri Hilir dalam Menarik Minat Pengunjung Objek Wisata Pantai Solop. Tujuan penelitian tersebut adalah untuk mengetahui strategi komunikator, strategi pemilihan khalayak, strategi penyusunan pesan, serta stratgi pemilihan media yang digunakan oleh Dinas Pariwisata, Kepemudaan dan Olahraga, dan Kebudayaan Kabupaten Indragiri Hilir. Penelitian tersebut merupakan penelitian kualitatif dengan metode pengumpulan data wawancara, observasi dan dokumentasi. Hasil penelitian menunjukkan bahwa strategi komunikator yang dilakukan oleh Dinas Pariwisata, Kepemudaan dan Olahraga, dan Kebudayaan Kabupaten Indragiri Hilir adalah dengan melakukan perencanaan, pengusulan, persiapan teknis dan pelaksanaan program. Pada tahapan selanjutnya, strategi penentuan khalayak dilakukan dengan membagi khalayak menjadi dua yaitu khalayak primer dan khalayak sekunder. Khalayak primer merupakan para pemuda yang terlibat langsung dalam kegiatan tersebut. Sedangkan khalayak sekunder merupakan masyarakat umum. Adapun strategi pesan yang digunakan adalah dengan langsung pada penekanan inti pesan dan melakukan pengorganisasian pesan. Strategi media yang digunakan adalah dengan menggunakan media konvensional berupa koran, televisi, radio; media luar ruangan seperti spanduk dan brosur, serta media baru seperti Facebook dan Instagram.

Berdasarkan pada kajian penelitian terdahulu yang telah dijabarkan di atas, dapat disimpulkan bahwa masih terdapat celah bahwa belum ditemukannya kajian penelitian terdahulu yang membahas mengenai Strategi Komunikasi Dinas Pariwisata Kota Palembang dalam Mempromosikan Destinasi Wisata di Kota Palembang Menjelang Asian Games XVIII 2018 (Studi Pada Program Paket Wisata Hemat "Palembang Asiik"). Pada ketiga kajian penelitian terdahulu tersebut menggunakan bermacam konsep untuk menjabarkan strategi komunikasi yang dilakukan Dinas Pariwisata terkait. Seperti pada penelitian yang dilakukan oleh Erizon (2014) menggunakan konsep unsurunsur komunikasi menurut Cangara dan menggunakan Teori Integrasi Informasi (Information Integration Theory). Sedangkan peneilitian yang dilakukan oleh Sugiarti et.al (2016) menggunakan konsep strategi perencanaan komunikasi menurut Anwar Arifin. Penelitian sebelumnya yang hampir sama dengan penelitian ini adalah penelitian yang dilakukan oleh Meilisa (2018), yaitu sama-sama menggunakan elemen komunikasi Lasswell dalam menjawab tujuan penelitian. Perbedaan dengan penelitian ini hanya pada subjek yang dikaji.

\section{METODE PENELITIAN}

Metode penelitian yang digunakan dalam penelitian ini adalah kualitatif dengan metode pengumpulan data observasi dan penelusuran di media massa online. Penelitian ini dibatasi pada strategi komunikasi yang dilakukan Dinas Pariwisata Kota Palembang dalam mempromosikan potensi wisata di Palembang yaitu meliputi elemen-elemen seperti komunikator, pesan, audiens, media dan efek.

\section{HASIL PENELITIAN DAN PEMBAHASAN}

Sebagai salah satu kota tersibuk di Indonesia, Palembang terus berbenah diri, khususnya pada infrastruktur sebagai sarana dan prasarana penunjang bagi aktivitas masyarakatnya. Terlebih pada tahun 2018 ini Palembang bersama dengan Jakarta menjadi tuan rumah Asian Games XVIII. Kota Palembang makin gencar melakukan pembangunan. Rupanya momen langka ini dimanfaatkan dengan baik oleh 


\section{National Conference of Creative Industry: \\ Sustainable Tourism Industry for Economic Development}

Universitas Bunda Mulia, Jakarta, 5-6 September 2018

E- ISSN No: 2622-7436

Pemerintahan Kota Palembang beserta jajaran terkait. Melalui sektor pariwisata untuk meningkatkan pendapatan daerah Sumatera Selatan, khususnya kota Palembang, Pemerintahan Kota Palembang, khususnya Dinas Pariwisata Kota Palembang merancang sebuah strategi yaitu melalui program paket wisata hemat "Palembang Asik".

Keberhasilan sebuah kegiatan komunikasi tidak lepas dari strategi komunikasi yang dilakukan. Seperti yang dijelaskan oleh Middlelton bahwa strategi komunikasi merupakan semua elemen komunikasi seperti komunikator, pesan, media, komunikan dan efek yang dikombinasikan dan dirancang demi optimalnya tujuan komunikasi yang diraih (Cangara, 2014). Sebagaimana yang diungkapkan oleh Middlelton tersebut Dinas Pariwisata Kota Palembang telah merancang strategi dengan matang yaitu melalui program paket wisata hemat "Palembang Asik". Strategi komunikasi yang dilakukan Dinas Pariwisata Kota Palembang demi keberhasilan program paket wisata hemat "Palembang Asik" ini dengan memanfaatkan semua elemen komunikasi menurut Lasswell, yaitu komunikator, pesan, media, komunikan dan efek agar tujuan yang telah ditetapkan dapat tercapai.

\section{Asosiasi Perusahaan Perjalanan Wisata Indonesia (Asita) Provinsi Sumatera Selatan sebagai Komunikator dalam Program Paket Wisata Hemat "Palembang Asik"}

Soemirat (2014) menjelaskan bahwa komunikator merupakan individu dan atau sekelompok individu yang mengirimkan pesan kepada orang lain. Tujuannya adalah untuk memengaruhi sikap, opini serta tindakan orang lain tersebut. Pada program paket wisata hemat "Palembang Asik" ini yang bertindak sebagai komunikator adalah Asosiasi Perusahaan Perjalanan Wisata Indonesia (Asita) Provinsi Sumatera Selatan. Sebagaimana dijelaskan oleh Cangara (2014) bahwa komunikator sebagai aktor utama dalam aktivitas komunikasi haruslah memiliki keterampilan berkomunikasi, kaya akan ide dan kreatif. Oleh karena itu pada program paket wisata hemat "Palembang Asik" ini Dinas Pariwisata Kota Palembang memilih 20 biro perjalanan wisata yang tergabung dalam Asosiasi Perusahaan Perjalanan Wisata Indonesia (Asita) Provinsi Sumatera Selatan. Program paket wisata hemat "Palembang Asik" mulai dilaksanakan pada 31 Maret 2017 hingga 31 Maret 2018 dan telah diperkenalkan kepada masyarakat pada 30 Maret 2017 di Hotel Arista, Palembang.

Penelitian yang dilakukan Meilisa (2018) menemukan hasil bahwa dalam menentukan komunikator Dinas Pariwisata, Kepemudaan dan Olahraga dan kebudayaan kabupaten Indragiri Hilir menetapkan individu-individu dengan kapasitas, kredibilitas serta pengetahuan yang luas mengenai objek wisata Pantai Solop. Hal ini dilakukan agar pesan yang disampaikan dapat diterima dengan baik. Inilah yang juga dilakukan oleh Dinas Pariwisata Kota Palembang. Demi merancang program paket wisata hemat "Palembang Asik", Dinas Pariwisata Kota Palembang membentuk konsorsium yang terdiri dari pengusaha-pengusaha yang bergerak dibidang pariwisata se-Sumatera Selatan. Dinas Pariwisata Kota Palembang memilih 20 biro perjalanan wisata ini karena melihat eksistensi dan kinerja yang telah mereka lakukan. Ke-20 biro perjalanan wisata ini memiliki jaringan agen terbesar di seluruh dunia dari Asia, Timur Tengah, Afrika sampai Eropa. Tentunya Dinas Pariwisata Kota Palembang meyakini ke-20 biro perjalanan wisata ini memiliki kapasitas yang tidak diragukan lagi dalam merangkul khalayak yang akan menjadi target sasaran mereka, terlebih jaringan luas yang telah dimiliki oleh biro perjalanan ini yang sangat luas hingga ke mancanegara. 


\section{National Conference of Creative Industry: \\ Sustainable Tourism Industry for Economic Development}

Universitas Bunda Mulia, Jakarta, 5-6 September 2018

E- ISSN No: 2622-7436

\section{Aman, Seru, Irit, Indah, dan Kenangan sebagai Pesan dalam Program Paket Wisata Hemat "Palembang Asik"}

Simons seperti dikutip oleh Soemirat (2014) menyatakan bahwa pesan adalah semua yang diucapkan oleh komunikator baik secara verbal (kata-kata dan tulisan) maupun non verbal (gerakan tubuh, nada suara, lirikan mata, dan lain-lain). Cangara (2014) menambahkan bahwa pesan tersebut dipersepsi dan diterima oleh komunikan dalam bentuk makna. Berkaitan dengan program paket wisata hemat "Palembang Asik", Dinas Pariwisata Kota Palembang merancang isi pesan yang disesuaikan dengan komunikan yang akan menerima pesan tersebut. Pesan yang dirancang pada program paket wisata "Palembang Asiik" ini yaitu aman, seru, irit, indah, dan kenangan.

Aman: Sebagai salah satu kota dengan tingkat kriminalitas tertinggi di Indonesia, Palembang berupaya untuk meminimalisir angka tindak kriminal yang terjadi, terlebih menjelang perhelatan Asian Games XVIII. Maka dari itu, untuk mengubah image sebagai kota dengan angka kriminalitas tertinggi, kota Palembang mempersembahkan tema "aman" ini agar masyarakat luar Palembang yakin bahwa Palembang saat ini merupakan kota yang aman.

Seru: Kota Palembang merupakan salah satu kota multietnis di Indonesia. Beragam etnis yang hidup brdampingan di kota Palembang ini mnjadi salah satu kseruan trsendiri yang akan dinikmati oleh para wisatawan. Hanya bermodalkan kurang dari satu juta rupiah perorang, wisatawan dapat menginap di Palembang selama tiga hari dua malam dengan dapat mengunjugi tempat-tempat seru diantaranya Jembatan Ampera, Benteng Kuto Besak, Monumen Perjuangan Rakyat, Kampung Kapitan, kampung Al Munawar, Kampung Sentra Songket, Bukit Siguntangm dan masih banyak lagi.

Irit: Harga menjadi pertimbangan utama bagi wisatawan untuk melakukan perjalanan ke suatu tempat. Dinas Pariwisata Kota Palembang dan ASITA mempromsikan paket hemat untuk wisatawan yaitu wisata tiga hari dua malam di kota Palembang dengan hanya membayar Rp.899.000,- untuk satu orang. ASITA sangat tertarik dan bersemangat memasarkan paket wisata ini karena dengan harga yang sangat trjangkau mereka yakin akan banyak mnarik minat masyarakat.

Indah: Belum banyak masyarakat yang mengetahui keindahan potensi wisata yang ada di kota Palembang. Di pulau Sumatera, Sumatera Utara dan Sumatera Barat menjadi destinasi wisata unggul dikarenakan keindahan potensi wisata yang dimiliki. Sumatera Utara dengan Danau Toba dan Pulau Samosirnya, sedangkan Sumatera Barat dengan Danau Singkaraknya. Bagaimana dengan Sumatera Selatan khususnya Kota Palembang? Keindahan potensi wisata yang dimiliki kota Palembang sebenarnya tidak kalah dengan yang ada di tempat lain. Palembang juga mempunyai beberapa potensi wisata yang memiliki keindahan dan nilai sejarah tinggi, salah satunya adalah Pulau Kemaro. Pulau ini letaknya sangat unik, yaitu berada di tengah sungai Musi dan membelah kota Palembang. Selain keindahan lokasinya, kisah dibalik sejarah pulau ini pun sangat indah, yaitu menganai kisah percintaan antara Siti Fatimah dan Tan Bun Ann yang sama-sama berdarah biru namun dari dua budaya yang berbeda.

Kenangan: Dinas Pariwisata Kota Palembang dan ASITA berharap para wisatawan yang berkunjung ke Palembang mendapatkan kenangan yang baik dan indah selama berkunjung ke Palembang. Oleh sebab itulah ASITA berjanji akan memberikan pelayanan yang prima mulai dari para wisatawan tiba di Bandara Sultan Mahmud 


\section{National Conference of Creative Industry: \\ Sustainable Tourism Industry for Economic Development}

Universitas Bunda Mulia, Jakarta, 5-6 September 2018

E- ISSN No: 2622-7436

Badarudin II hingga pulang kembali ke bandara. Hal tersebut dilakukan supaya para wisatawan yang berkunjung tersebut bersedia kembali lagi ke Kota Palembang.

Diharapkan dengan suguhan yang diberikan Dinas Pariwisata Kota Palembang wisatawan mancanegara yang menjadi khalayak sasaran, memiliki rasa aman ketika berkunjung ke kota Palembang, senang dengan suguhan objek wisata kota Palembang yang seru, irit dengan biaya wisata di kota Palembang yang murah untuk menikmati potensi wisata kota Palembang yang indah dan terkenang akan keramahan pelayanan dan masyarakat kota Palembang sehingga nanti mereka bersedia datang kembali ke kota Palembang.

Hasil penelitian Sugiarti et.al (2016) mengenai strategi komunikasi yang dilakukan Dinas Kebudayaan dan Pariwisata Kabupaten Buton Tengah diketahui bahwa dalam penyusunan pesan Dinas Kebudayaan dan Pariwisata Kabupaten Buton Tengah melakukan penyesuaian pesan dengan khalayak sasarannya. Pesan disampaikan dengan dengan cara persuasif dan informatif. Begitu pun yang dilakukan oleh Dinas Pariwisata Kota Palembang yang juga menyampaiakn pesan yang persuasif dan informatif kepada khalayak sasaran agar mereka bersedia berkunjung ke kota Palembang.

Sayangnya dalam perancangan pesan yang dilakukan oleh Dinas Pariwisata Kota Palembang tidak menggunakan bahasa Inggris. Padahal target sasaran utama pada program paket wisata "Palembang Asiik" ini adalah wisatawan mancanegara. Padahal Cangara (2014) dengan jelas menyatakan bahwa pentingnya untuk memahami karakter dari masyarakat yang menjadi target sasaran suatu program komunikasi yang kita rancang.

\section{Media Konvensional, Media Baru dan event sebagai Media yang digunakan dalam Program Paket Wisata Hemat "Palembang Asik"}

Soemirat (2014) menjelaskan bahwa media atau saluran adalah sarana yang dipergunakan untuk mengirimkan pesan kepada khalayak sasaran. Pada suatu program komunikasi, media yang digunakan umumnya menggunakan media massa. Inilah yang dilakukan oleh Dinas Pariwisata Kota Palembang dalam merancang program paket wisata murah "Palembang Asiik". Media yang digunakan untuk mempromosikan program ini adalah media konvensional seperti Televisi, Radio dan surat kabar. Selain itu media lainnya yang digunakan adalah media baru atau internet, yaitu pada portal berita online dan media sosial. Cangara (2014) menjelaskan bahwa perlu dilakukan pertimbangan terhadap pemilihan media komunikasi yang sesuai supaya pesan yang disampaikan tepat sasaran, yaitu pertimbangan mengenai khalayak sasaran dan jenis media yang mereka gunakan. Pada konteks ini Dinas Pariwisata Kota Palembang ikut serta dalam event pameran pariwisata di mancanegara yang dibantu oleh beberapa biro perjalanan wisata di Palembang.

Tidak berbeda jauh dilakukan oleh Dinas pariwisata, kepemudaan dan olahraga dan kebudayaan kabupaten Indragiri Hilir. Demi menarik minat pngunjung objek wisata pantai Solop, Dinas pariwisata, kepemudaan dan olahraga dan kebudayaan kabupaten Indragiri Hilir mengguanakan beberapa media seperti media cetak seperti koran, brosur dan spanduk; media elektronik seperti radio dan televisi; serta internet (Meilisa, 2018).

Berbeda dengan Dinas Pariwisata Pemuda dan Olahraga Kabupaten Kampar yang selain memanfaatkan media massa konvensional, internet dan event juga memanfaatkan majalah dan buku dalam mempromosikan Wisata Candi Muara Takus Erizon (2014). 


\section{National Conference of Creative Industry: \\ Sustainable Tourism Industry for Economic Development}

Universitas Bunda Mulia, Jakarta, 5-6 September 2018

E- ISSN No: 2622-7436

\section{Wisatawan Mancanegara sebagai Khalayak Sasaran dalam Program Paket Wisata Hemat "Palembang Asik"}

Mulyana (2012) menyatakan bahwa audiens atau komunikan atau khalayak sasaran merupakan penerima pesan yang diberikan oleh sumber atau komunikator. Mereka juga merupakan target sasaran dari suatu program komunikasi. Pada program paket wisata hemat "Palembang Asiik" ini, Dinas Pariwisata Kota Palembang menargetkan wisata mancanegara sebagai sasaran. Dinas Pariwisata Kota Palembang mengincar wisatawan mancanegara sebagai target sasaran karena memanfaatkan momen perhelatan Asian Games XVIII pada tahun 2018.

Sebagaimana yang dijelaskan oleh Cangara (2014) bahwa penting untuk memahami karakter dari masyarakat yang menjadi target sasaran suatu program komunikasi yang kita rancang. Seiring dengan pernyataan Cangara tersebut, Dinas Pariwisata Kota Palembang telah memikirkan hal tersebut dengan matang. Dinas Pariwisata Kota Palembang melakukan beberapa riset mengenai apa yang menjadi keinginan wisatawan mancangara saat ini. Selain kuliner, hal lain yang disukai oleh wisatawan mancanegara adalah potensi wisata yang memiliki kearifan lokal yang kuat. Beruntungnya kedua hal ini telah dimiliki oleh kota Palembang.

Palembang memiliki banyak kuliner khas yang bercita rasa unik. Bahkan beberapa kuliner khas Palembang telah digemari oleh masyarakat luar Palembang, seperti Pempek. Selain pempek, kuliner lain yang dapat memanjakan lidah wisatawan asing adalah tekwan, lenggang, mie celor, martabak kuah kari, es kacang merah, pindang patin, tempoyak, dan masih banyak lagi.

Kota Palembang mempunyai keunikan tersendiri karena memiliki kebudayaan yang beragam dalam satu kota. Kota Palembang merupakan kota dengan kombinasi tiga budaya asli, yaitu Melayu, Tionghoa dan Arab. Masyarakat kota Palembang dengan tiga budaya berbeda tersebut hidup rukun berdampingan tanpa pernah adanya konflik etnis. Di kota Palembang terdapat tiga perkampungan yang memiliki kearifan lokal sesuai tiga kbudayaan tadi, yaitu Kampung Al Munawar di 13 Ulu yang merupakan kampung Arab, Kampung Kapitan di 7 Ulu yang merupakan kampung bagi etnis Tionghoa dan Kampung Palembang Lorong Firma 4 Ulu yang merupakan perkampungan etnis Palembang asli. Masing-masing kampung etnis ini memiliki nilai sejarah yang tinggi dan kearifan lokal yang tetap dijalankan secara turun-tmurun. Ketiga perkampungan bernuansa kearifan lokal inilah yang diyakini Dinas Pariwisata Kota Palembang sebagai potensi wisata yang akan digemari oleh wisatawan mancanegara.

Berdasarkan penelitian yang dilakukan oleh Meilisa (2018) diketahui bahwa srategi penentuan khalayak dilakukan yaitu dengan membagi khalayak menjadi dua yaitu khalayak primer dan khalayak sekunder. Khalayak primer merupakan para pemuda yang terlibat langsung dalam berbagai kegiatan yang diselenggarakan oleh Dinas Pariwisata, Kepemudaan dan Olahraga dan Kebudayaan kabupaten Indragiri Hilir. Sedangkan khalayak sekunder merupakan masyarakat umum yang tidak terlibat langsung dengan berbagai kegiatan yang diselenggarakan oleh Dinas Pariwisata, Kepemudaan dan Olahraga dan Kebudayaan kabupaten Indragiri Hilir.

Memahami karakter wisatawan asing menjadi hal yang sangat penting dilakukan oleh penyelenggara suatu program komunikasi. Begitupun bagi Dinas Pariwisata Kota Palembang karena merekalah yang menjadi penentu bagi keberhasilan program komunikasi yang telah Dinas Pariwisata Kota Palembang dirancang. Mulyana (2012) menyatakan bahwa berkaitan dengan proses penerimaan pesan dan selanjutnya 
pemaknaan pesan yang dilakukan oleh wisatawan mancanegara tentunya dipengaruhi oleh beragam aspek, diantaranya adalah pengalaman masa lalu, nilai-nilai, pengetahuan, persepsi, pola pikir, dan perasaan yang dimiliki. Diharapkan wisatawan mancangara memiliki nilai positif setelah berkunjung ke kota Palembang.

\section{Efek yang dihasilkan}

Mulyana (2012) menjelaskan bahwa efek adalah hasil akhir dari proses komunikasi, yang mana pesan telah diterima oleh khalayak. Setelah program paket wisata hemat "Palembang Asiik" diterima oleh wisatawan mancanegara yang merupakan khalayak sasaran, timbul efek yang didapat. Pada tingkatan awal, yaitu pada ranah pengetahuan, wisatawan mancanegara yang tadinya tidak tahu menjadi tahu informasi mengenai paket wisata hemat "Palembang Asiik". Pada tingkatan selanjutnya adalah pada ranah sikap, wisatawan mancanegara yang tadinya tidak menyukai Palembang dapat berubah menjadi menyukai Palembang. Terakhir, pada ranah perilaku, wisatawan mancanegara yang tadinya tidak bersedia ke Palembang menjadi bersedia datang ke Palembang setelah melihat paket wisata hemat "Palembang Asiik". Dengan demikian efek yang didapatkan dari strategi komunikasi yang dilakukan oleh Dinas Pariwisata Kota Palembang ini adalah meningkatnya jumlah wisatawan, khususnya wisatawan asing yang datang ke kota Palembang.

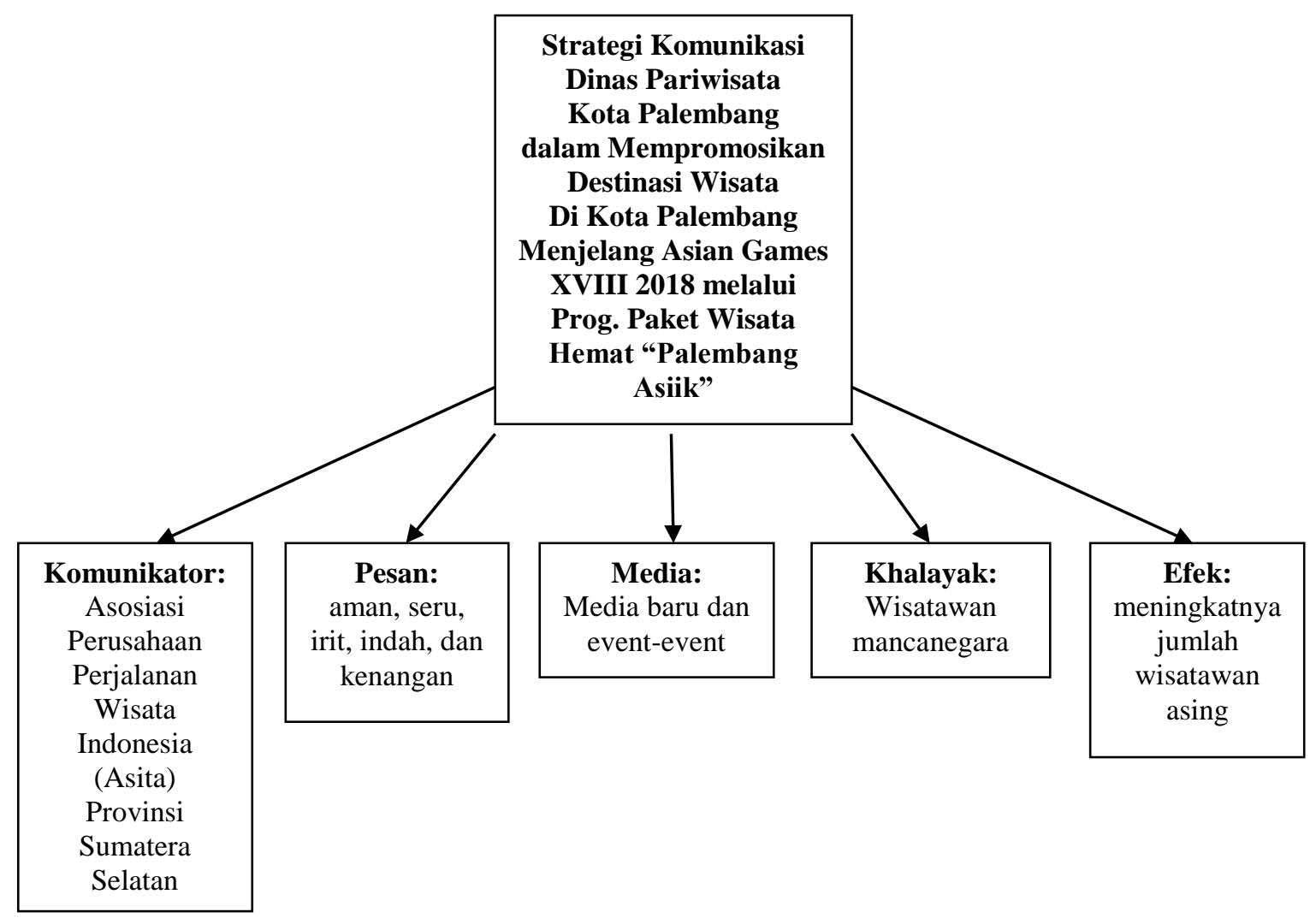

Gambar 1. Strategi Komunikasi Dinas Pariwisata Kota Palembang dalam Mempromosikan Prog. Paket Wisata Hemat "Palembang Asiik" 


\section{National Conference of Creative Industry: \\ Sustainable Tourism Industry for Economic Development}

Universitas Bunda Mulia, Jakarta, 5-6 September 2018

E- ISSN No: 2622-7436

\section{KESIMPULAN DAN IMPLIKASI}

Berdasarkan tujuan penulisan penelitian ini dapat disimpulkan bahwa dalam mempromosikan program Paket Wisata Hemat "Palembang Asiik", Dinas Pariwisata Kota Palembang memilih 20 biro perjalanan wisata yang tergabung dalam Asosiasi Perusahaan Perjalanan Wisata Indonesia (Asita) Provinsi Sumatera Selatan sebagai komunikator. Pesan yang dirancang dalam program paket wisata "Palembang Asiik" ini adalah aman, seru, irit, indah, dan kenangan. Media yang digunakan untuk mempromosikan program ini diantaranya adalah media konvensional (televisi, radio dan surat kabar), media baru (portal berita online dan sosial media) serta pelaksanaan eventevent pariwisata di luar negeri. Khalayak sasaran dalam program wisata ini adalah wisatawan mancanegara, khususnya Asia. Adapun efek yang didapatkan dari strategi komunikasi yang dilakukan oleh Dinas Pariwisata Kota Palembang dalam mempromosikan program Paket Wisata Hemat "Palembang Asiik" ini adalah meningkatnya jumlah wisatawan, khususnya wisatawan asing yang datang ke kota Palembang.

Hasil penelitian ini merekomendasikan agar pada perencanaan program komunikasi hendaknya menyesuaikan pesan dengan target sasaran utama agar pesan dapat sampai dengan ektif dan hasilnya pun maksimal.

\section{DAFTAR PUSTAKA}

Cangara, H. (2014). Perencanaan \& Strategi Komunikasi. Jakarta: PT. Raja Grafindo Persada.

Effendy, Onong U. (2007). Ilmu Komunikasi, Teori dan Praktek. Bandung: PT. Remaja Rosdakarya.

Erizon, Muhammad (2014), Strategi Komunikasi Dinas Pariwisata PemudaDan Olahraga Kabupaten Kampar DalamMempromosikan WisataCandi Muara Takus, Pekanbaru: Universitas Islan Syarif Kasim.

Meilisa, Veni Fitra. (2018). Strategi Komunikasi Dinas Pariwisata, Kepemudaan dan Olahraga, dan Kebudayaan Kabupaten Indragiri Hilir dalam Menarik Minat Pengunjung Objek Wisata Pantai Solop. JOM FISIP Vol. 5 No. 1 - April 2018.

Mulyana, Deddy. (2013). Ilmu Komunikasi, Suatu Pengantar (Cetakan Kelimabelas). Remaja Rosdakarya. Bandung.

Soekadijo, R.G. (2000). Anatomi Pariwisata (Memahami Pariwisata Sebagai "Systemic Linkage". Jakarta : Gramedia Pustaka Utama.

Soemirat, S, Hidayat Satari dan Asep Suryana. (2014). Komunikasi Persuasif. Jakarta.Universitas Terbuka.

Suryadana, Liga dan Vanny Oktavia. (2015). Pemasaran Pariwisata. Bandung: Alfabeta.

Sugiarti, Thesar, Amin, Hasriani, \& Rezkyawati, S.U. (2016). Strategi Komunikasi Dinas Kebudayaan Dan Pariwisata Dalam Pemetaan Potensi Wisata Kabupaten Buton Tengah. Journal Ilmu Komunikasi UHO, Vol. 1, No.2.

\section{Sumber Elektronik/Internet}

Asdhiana, I Made. 2017. "Palembang Asiik", Paket Hemat Berwisata di "Kota Pempek". Diakses pada 12 Juli 2018, dari 
https://travel.kompas.com/read/2017/04/06/084100927/.palembang.asiik.paket.he mat.berwisata.di.kota.pempek.

Rosana, Dolly. 2017. Pemkot luncurkan paket wisata "Palembang Asiik". Diakses pada 12 Juli 2018, dari https://sumsel.antaranews.com/berita/313595/pemkotluncurkan-paket-wisata-palembang-asiik.

Tasmalinda. 2018. Palembang Akan Populerkan Kuliner dan Budaya saat Asean Games. Diakses pada 12 Juli 2018, dari https://www.gatra.com/rubrik/hiburan/wisata/317853-palembang-akan populerkan-kuliner-dan-budaya-saat-asian-games. 